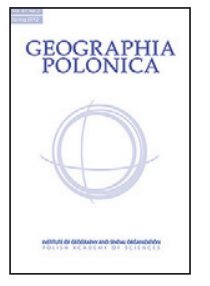

\title{
REGIONAL DIVERGENCE DYNAMICS IN THE BALTIC REGION: TOWARDS POLARISATION OR EQUALIZATION?
}

\author{
Gennady M. Fedorov • Andrey S. Mikhaylov \\ Immanuel Kant Baltic Federal University \\ A. Nevskogo 14, 236016, Kaliningrad: Russian Federation \\ e-mails: gfedorov@kantiana.ru • mikhailov.andrey@yahoo.com
}

\begin{abstract}
Regional socio-economic inequality is a major threat of instability in northeast Europe. The polarisation-equalization dynamics has a direct influence over the distribution of population, industry, financial resources, environmental load, and other domains of the Baltic region. The research scope covers an area of nine countries, including the Baltic coast of Germany, Poland, and north-western Russia. Official data of Eurostat and Rosstat are used to evaluate the relationship between a number of statistical indicators over a period of 2000-2016. Research results reveal an inverse correlation between the volume of GRP per capita generated and the rate of its increase, as well as between GRP per capita and population change. A less significant direct correlation between population density and the rate of population increase found. Results emphasise cross-country differences in polarisation and equalization processes and stress that the population of the Baltic region is increasingly concentrating in capital cities. The latter is especially evident in countries with a relatively small population size. An important factor affecting the development of international cooperation in the Baltic region and national economic growth is the high economic growth rates in the less economically developed countries. The article puts forward arguments in favour of regional equalization and advocates against polarisation strategy, including special measures to stimulate growth of urban agglomerations.
\end{abstract}

\section{Key words}

inequality dynamics $\cdot$ regional divergence $\cdot$ polarisation $\cdot$ equalization $\cdot$ Baltic region

\section{Introduction}

The Baltic region is one of the most rapidly developing European macro-regions in terms of socio-economic cooperation and integration between countries, regions, and municipalities. The general pan-European trend on transparency and openness after the
World War II was followed by intensification of socio-cultural, economic and political interactions when the USSR collapsed and the former socialist countries have initiated a transition towards the market economy. The latest impetus that boosted the integrity (at least partial) of the Baltic region was the enlargement of the European Union and the acces- 
sion of new member-states in 2004 - Estonia, Latvia, Lithuania, and Poland (Scott 2002).

The density of national borders makes the Baltic region one of the dynamic macroregions with respect to cross-border cooperation and transnational regionalization (Kern \& Löffelsend 2004; Lepik 2009). Of 185 crossborder regions officially registered in Europe by Association of European Border Regions, 26 belong to the Baltic region. There are dozens of cross-border cooperation projects undertaken over the past quarter of a century resulting in numerous cross-border clusters being established between the borderland areas of the Baltic region (Kiryushin et al. 2013; Mikhaylov \& Mikhaylova 2014; Park 2014; Rohde 2016). As it is noted by Melnikas (2008a, b), the Baltic region manifests itself as a geopolitical, social and economic community, featuring a trend on an integrated socio-economic system.

The common marine basin of the Baltic Sea is found to be the enabling factor for building common ground on various socio-cultural, political and especially environmental issues (Backer 2011). Marine coast acts as binder since early 1970s, when the post-war transformation of the Baltic into "a sea of peaceful cooperation" (Pacuk et al. 2018: 54) was launched with the signing of the Gdańsk Convention on Fishing and Conservation of the Living Resources in the Baltic Sea and the Belts in 1973, and the Convention on the Protection of the Marine Environment of the Baltic Sea Area in 1974 between Denmark, Finland, Sweden, FRG, GDR, Poland and the USSR.

All of the aforementioned factors have contributed to anchoring the delimitation boundaries of the Baltic region area. Scholars increasingly mention it as a macro-region with self-identity (Agh 2012), an existing cognitive region (Scott 2002). Although, despite noticeable changes in institutional coherence it remains highly heterogeneous in many respects. Mikhailova (2013) classifies the countries of the Baltic region by the level of scientific and technological potential: countries of high scientific and technological development - Sweden, Germany, Finland and Denmark; average values are found in Estonia and Norway; low values of the integral index are registered in Russia, Latvia, Poland, and Lithuania. Another segregation is offered by Paas (2003) who divided countries into three groups on the basis of their relationship with the European Union: eastward enlargement (featuring transitional countries except for Russia), the EU-member states (all the industrialized countries except for Norway), the EU-associated industrialized Norway and the non-associated transitional Russia. Pettersson (2002) offers another approach based on differences in culture, dividing the Baltic region into four different cultural zones: the Protestant Europe (Nordic countries, Germany), the Ex-communist Baltic (Estonia, Lithuania, and Latvia), the Orthodox (Russia), and Catholic Europe (Poland).

Despite the changes in economic performance of the East European countries (Poland, Latvia, Lithuania, Estonia) they still lag behind the developed countries (Germany, Denmark, Finland, and Sweden), and the differences between the two groups of countries remain substantial (Druzhinin \& Prokopyev 2018). According to Koch (2015), the gap that indicates economic disparities between older and newer market economies of the Baltic region countries remains significant and is even widening, which is threatening the stability in Northeast Europe. The objective of this paper is to capture the dynamics of spatial divergence across the Baltic region, providing an insight on whether the socio-economic polarization between countries deepens.

\section{Literature review}

Disparities in the socio-economic development of countries and regions resulting from an interplay of objective (e.g. environmental, demographic) and subjective (e.g. institutional) factors are said to be a natural phenomenon in economics (Perroux 1955; Boudeville 1966; Friedmann 1967; Lasuen 1969). Differences in availability and management of productive forces, the national and regional institutional setup, as well as knowledge capacity shape the 
competitive advantage of national and regional economies. This fact forms the basic principles behind international division of labour, international intra- and cross-industry cooperation, as well as functional integration along the value chain. Countries and regions standing high in the value chain are those gaining a higher rate of return by performing highermargin operations (e.g. research and design, services), whereas the lowest are those providing an input of raw materials, (low-skilled) labour force, and land resources.

Numerous contemporary concepts argue that highly integrated territorial socioeconomic systems are expected to enjoy the effects of innovation diffusion (Morgan 2007; Asheim \& Gertler 2009), knowledge spillovers (Capello 1999; Caragliu \& Nijkamp 2016), and other positive externalities (Capello \& Faggian 2005; Petruzzelli et al. 2009; Koliousis et al. 2018) that contribute to spatial convergence. These arguments follow the traditional perception of development cycles made in the early XX century by Kuznets (1955), and Williamson (1965) who further transposed this pattern towards the regional divide. The initial increase in economic inequality is considered temporary and is projected to level out with the dissemination of the initial benefits of the 'leaders' in favour of lagging territories. Some recent studies confirm this allegation on a national level where the subsequent redistribution of welfare is implemented via state policies (Stead 2013; Epstein 2014). A number of scholars have verified this pattern in the scope of European Union (De Dominicis 2014; Dyba et al. 2018) and Russia (Chistobaev 2013; Baklanov 2016; Anokhin \& Fedorov 2017). Public expectations over the gradual socio-economic equalization with neighbouring countries are strong in the EU member-states as representatives of a single community (Berger-Schmitt 2002; Blockmans 2006) as well as Russia - the country with richest natural resources in the World. Selfawareness of regional communities as a part of the Baltic region sets a benchmark sample in minds of citizens of less advanced territories who anticipate a similar standard of liv- ing. Social tension on these matters is especially apparent in borderland regions where residents experience daily commutes across borders (Delhey \& Kohler 2006).

Multiple cohesion policy instruments in Europe support regional convergence both within and beyond European Union (EU Strategy for the Baltic Sea Region 2015; Regional Investment Plan 2015; Action Plan for the European Union Strategy for the Baltic Sea Region 2017). In Russia, there are numerous regional place-specific strategies (Arctic, FarEast, etc.) and the Strategy on spatial development of the Russian Federation till 2030. However, the enhancement of SMEs competitiveness and technological development in lagging regions represents only a portion of supported initiatives, being dominated by social and environmental aspects.

Clustering of economic activity is still an objective reality despite and even due to globalization, enhancement of ICT, and a reduction in transportation costs. Change in prerequisites of co-location from traditional factors of production towards intangible capabilities of the territorial capital (Capello et al. 2011; Perucca 2014; Toth 2014; Camagni 2017) - knowledge, skills, competencies, etc. form the basis of modern growth poles (e.g. innovative milieus, regional clusters, learning regions). Although new poles of competitiveness may appear - resulting from regional cluster initiatives, science parks, business incubators, technology-transfer centres, technology districts, etc., economically prosperous regions continue to develop at a more rapid pace. This results in increasing regional polarisation, i.e. growing differentiation between countries and regions by their level of development.

The groundwork in providing a rationale for this process using mathematical modelling is made by Paul Krugman (1991). In 2008, Krugman was awarded the Nobel Prize and the same year the World Bank report on Reshaping Economic Geography has employed his findings in providing recommendations on spatial planning. The new perspective supports the benefits of economic 
polarisation, which translates into a higher return on investment. Thus, it is recommended to stimulate more developed regions in order to ensure higher development rates on a national scale (Bourdin 2013; Gyuris 2013; Kisiała \& Suszyńska 2017). Similar recommendations are given in the context of Russia (Nizhegorodtsev 2008; Seliverstov 2008; Kinossian 2013; Gladkiy 2014; Zubarevich 2015; Makhrova et al. 2016; Berezhnoy et al. 2017). Despite receiving mixed reaction of scholars throughout the globe (see: Garretsen \& Martin 2010; Pilyasov 2011; Baklanov 2012; Melnikova 2014; Hassink 2016; Gaspar 2018), the new approach is adopted by policymakers and the academic community.

The central questions of regional planning are as follows: Regions of which level need priority support for economic development and do they need it at all? Should equalization be attainted through priority support for less advanced areas or through stimulating the accelerated development of regional leaders, whose increased profits will be redistributed later to the least advanced regions?

\section{Methodology}

According to the definition used in this article, the Baltic region includes the entire territories of Sweden, Denmark, Finland, Lithuania, Latvia, and Estonia, as well as the coastal areas of Germany, Poland, and North-Western Russia. This approach is coherent with previous studies held by Klemeshev et al. (2017), Kretinin et al. (2016), Mezhevich et al. (2016) and other scholars focusing on human geography. The research scope incorporates statistical data on both the countrywide level and the level of administrative-territorial units division corresponding to the third level of a common classification of territorial units for statistics (NUTS 3) of the European Commission (2015). The data on the gross domestic product (GDP) in purchasing power parity (PPP) per capita in USD for all countries of the Baltic region for a period of 2000-2016 is sourced from the World Factbook (2017) of the US Central Intelligence Agency. The population density figures and gross regional product (GRP) data evaluated per capita at current market prices for the micro-regions (NUTS 3) of nine states considered are acquired from Eurostat (the European Statistical Office, http://ec.europa.eu/Eurostat) and Rosstat (the Federal State Statistics Service of the Russian Federation, http://www.gks. ru) for a period of 2005-2014. The GRP data for the European Union member-states are given in Euro, while Rosstat accounts originally given in Rubles are recalculated at the official annual average exchange rate of the Central Bank of Russia for 2006 (1 EUR = 34.1144 RUB). The correlation analysis is held to examine the relationship between GDP/ GRP values and the rate of increase over the studied period. A similar approach is applied to identifying the relationship between population density and change in values over the studied period.

\section{Research results}

In 2000-2016, the Baltic region states had an inverse relationship between the GDP rate of increase to the GDP per capita values of 2000 (Fig. 1). The linear correlation coefficient reached 0.59 . The GDP values were increasing in all post-socialist countries of the Baltic region at a much higher rate than in countries with a traditional market economy. It is found that the lower is the initial level of GDP per capita the higher is the growth rate. In the countries that are more economically developed the differences in GDP increase rates also depended on the initial level of values. However, the gap is not as wide as in the case of post-socialist states.

The distribution of NUTS 3 territories in the EU countries of the Baltic region and in North-West Russia by GRP values are shown in Figure 2. The figure demonstrates a negative correlation between the GRP values and the rate of increase over the studied period. The linear correlation coefficient is -0.55 . However, the values calculated for each country differ significantly from the regional average. Negative values are observed in the 


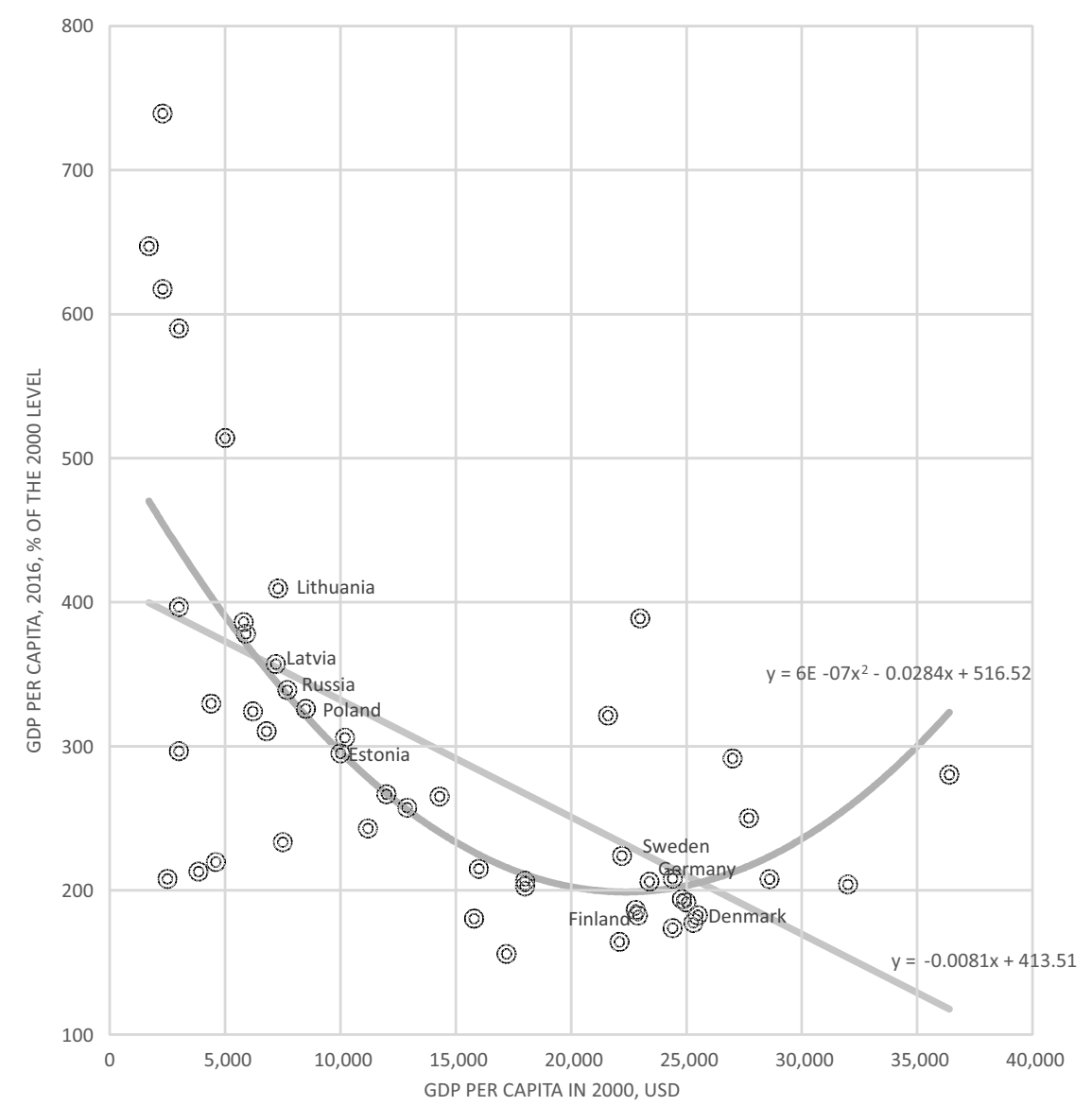

Figure 1. Distribution of the Baltic region countries by GDP(PPP) per capita dynamics

Source: based on the World Factbook (2017).

micro-regions of Finland (-0.52), Germany $(-0.25)$, the Baltic States $(-0.47)$, and Russia's North-West (-0.32). In three countries, the coefficient is positive. These are Denmark (0.70), Sweden (0.50), and Poland (0.14). The absolute values of the correlation coefficient in Poland, Germany, and Russia are rather low. Thus, the straight-line correlation is weak. Changes in GRP are affected by other factors to a much greater degree. Using GDP per capita values to estimate the development of countries and regions leads us to conclude that the equalization process is typical for the Baltic region. Denmark and Sweden stand out with high positive coefficients of linear corre- lation between volume and changes in GRP per capita values.

The general perception over socio-spatial divergence implies that advanced regions characterized by higher population density continue to attract people with migration influx contributing to an increase in the population size of such areas. On the contrary, less developed territories experience a decline in the population against the background of high immigration (or even in the case of a slightly positive net migration rate). The rate of natural increase is mostly negative throughout the Baltic region. Cross-country and cross-regional differences are insig- 


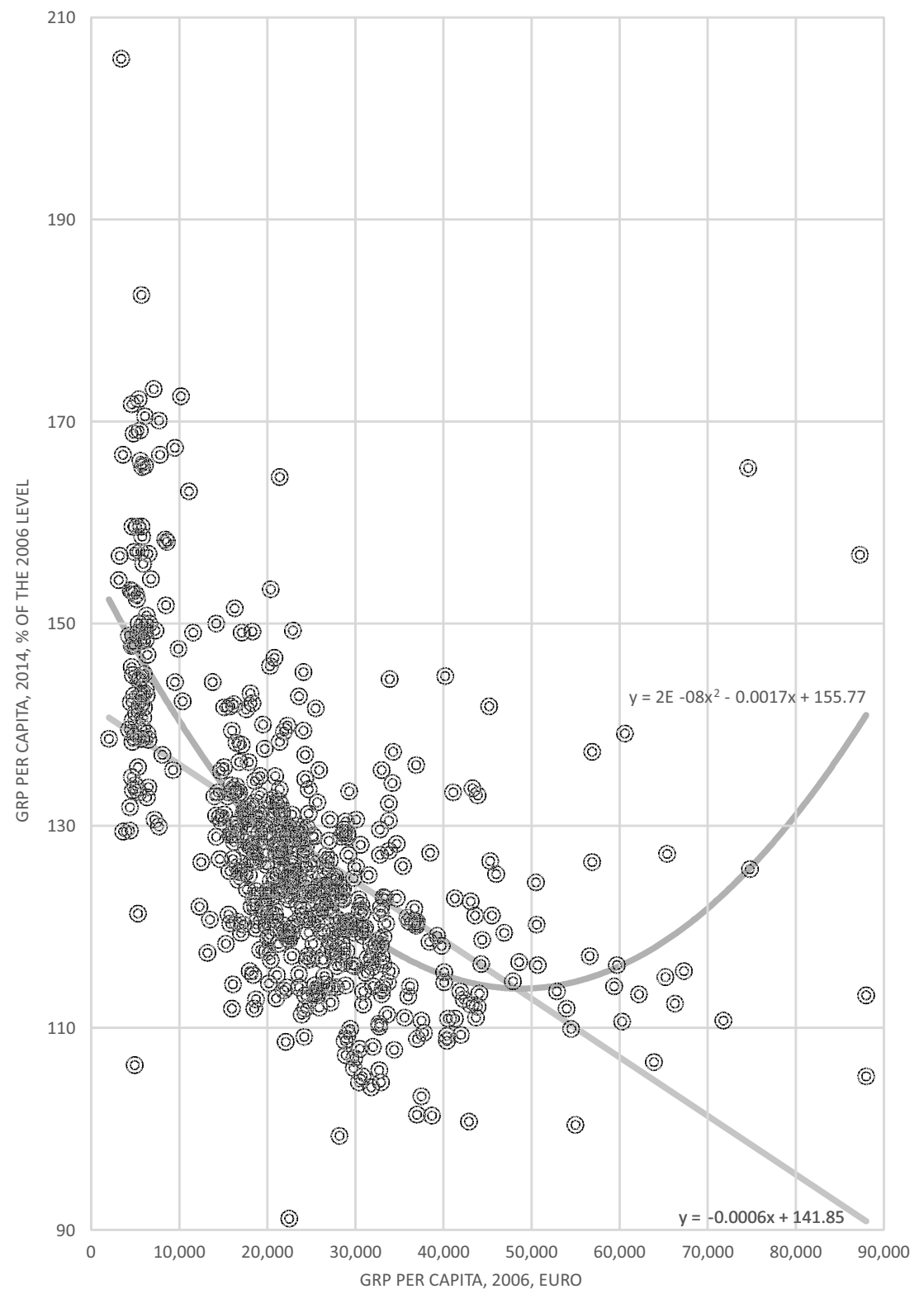

Figure 2. Distribution of NUTS 3 territories of the Baltic region by GRP dynamics Source: based on Eurostat and Rosstat statistical databases.

nificant. The population change is primarily affected by migration.

Our calculations do not support the hypothesis about a persistent universal trend towards population concentrating in the most advanced regions. In 2010-2015, the coefficient of linear correlation between population density and change in the Baltic region was positive but did not exceed 0.22. Figure 3 shows a slight tendency towards population 


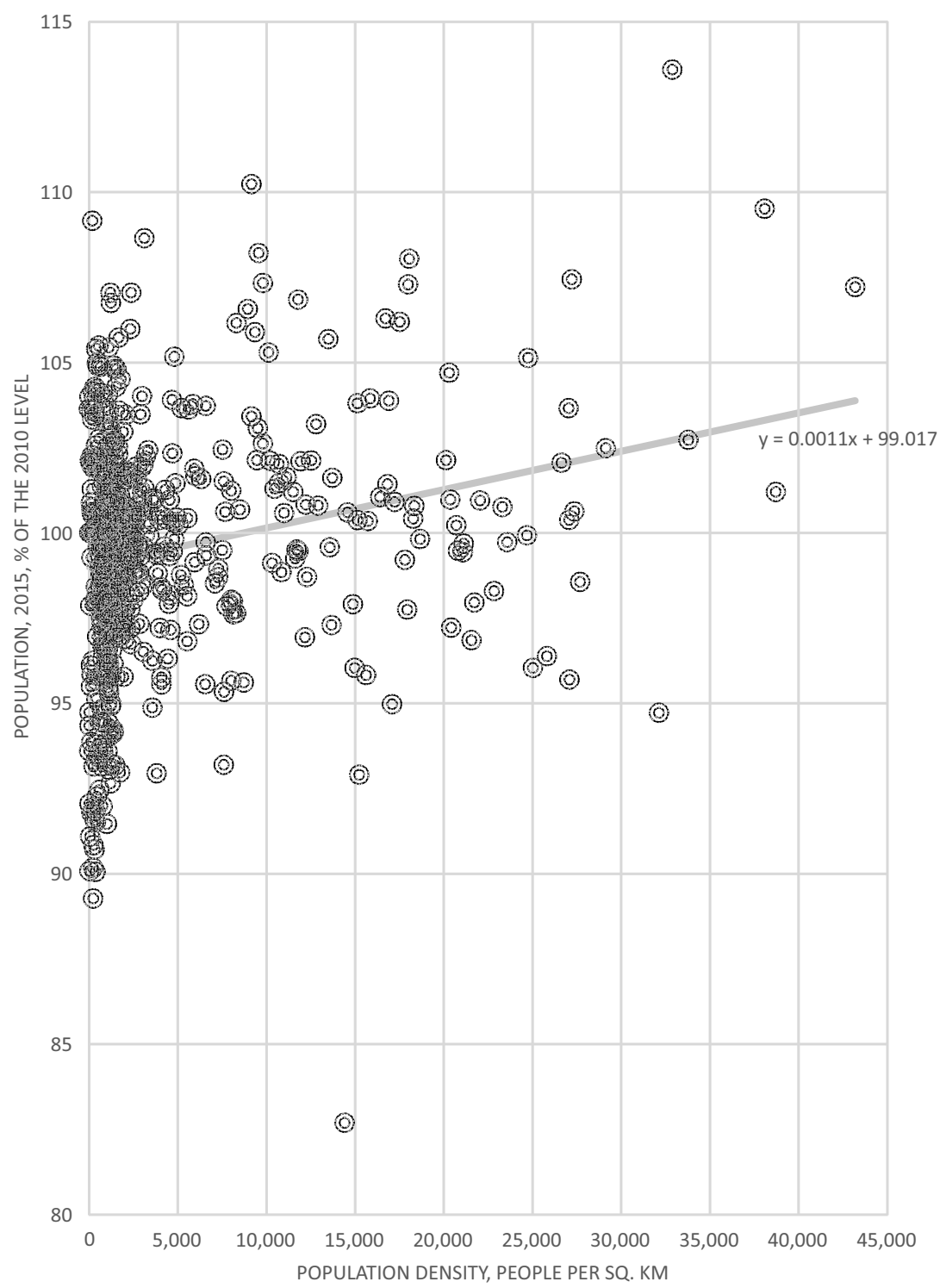

Figure 3. Distribution of NUTS 3 territories of the Baltic region by population density dynamics Source: based on Eurostat and Rosstat statistical databases.

increase in the most advanced regions and towards population decline in regions with a reduced density.

Smaller countries of the region have a rather high positive correlation coefficient. This suggests that the indicators have a significant correlation. The coefficient reaches 0.90 in Lithuania, 0.75 in Denmark, 0.74 in Sweden, and 0.67 in Estonia. In Finland, the coefficient does not exceed 0.52. In North-West Russia the coefficient is also rather high, reaching 0.64 . The high values are explained by the considerable contribution of the country's capitals and Saint Peters- 
burg. Unlike other cities, metropolitan areas demonstrate a very high rate of population increase being a result of migration influx (Tab. 1). This strongly affects the values of the correlation coefficient.

In smaller states, only Latvia has a rather low coefficient of 0.36 . The coefficient is also low in larger states - 0.25 in Germany and 0.34 throughout Russia. In Poland, the correlation coefficient of -0.01 does not demonstrate a relationship between population density and its dynamics over time. When analysing territorial differences in population change, it is important to pay attention to factors other than population density and overall regional development.

Figure 4 provides interesting findings regarding the distribution of NUTS 3 regions based on the correlation between population change and increase in GRP per capita. There is a trend towards an inverse correlation between these indicators. Another proof of the existence of such a trend is the coefficient of linear correlation, which reaches -0.19. The calculations do not support the hypotheses about the economic benefit of the continuing concentration of people in densely populated areas. This questions the thesis about the need to stimulate such overconcentration.

\section{Conclusion}

Assessment of regional divergence dynamics in the Baltic region expressed in the changing differences of GRP per capita reveals a trend for the gap reduction in the 2000s, featuring a reduction in economic development differences across states. This pattern significantly differs from the 1990s, when the developmental gap between the East and the West was growing (particularly, during the primacy of command economies and state ownership in Eastern Europe). The pattern remained during the transition of former Socialist countries to a market economy. Thus, the inter-country differences increased at first and started to reduce in the new millennium. When graphed, the trend produces an inverted $U$ curve.

Regional scope analysis demonstrates a trend towards an inverse correlation between the volume and dynamics of GRP per capita values and between population

Table 1. Population dynamics in the capital cities and Saint Petersburg, as compared to the national population change

\begin{tabular}{|l|r|l|c|}
\hline \multicolumn{2}{|c|}{ NUTS 3 } & \multicolumn{2}{c|}{ State, Federal District of Russia } \\
\hline \multicolumn{1}{|c|}{ NUTS 3 } & $\begin{array}{c}\text { Population, } \\
\text { 2016, of the 2005 level }\end{array}$ & \multicolumn{1}{c|}{$\begin{array}{c}\text { Population, } \\
\text { 2016, \% of the 2005 level }\end{array}$} \\
\hline Copenhagen & $116.0^{\star}$ & Denmark & $104.8^{\star}$ \\
Berlin & 103.9 & Germany & 99.6 \\
North Estonia & 106.9 & Estonia & 96.8 \\
Riga & 89.8 & Latvia & 87.5 \\
Vilnius County & 96.0 & Lithuania & 86.1 \\
City of Warsaw & 102.8 & Poland & 99.5 \\
Helsinki-Uusimaa & 112.6 & Finland & 104.8 \\
Stockholm County & 119.1 & Sweden & 109.3 \\
Saint Petersburg & 111.5 & Russia's North-Western & 101.0 \\
\hline
\end{tabular}

${ }^{\star} 2016, \%$ of the 2007 level.

Source: based on Eurostat and Rosstat statistical databases. 


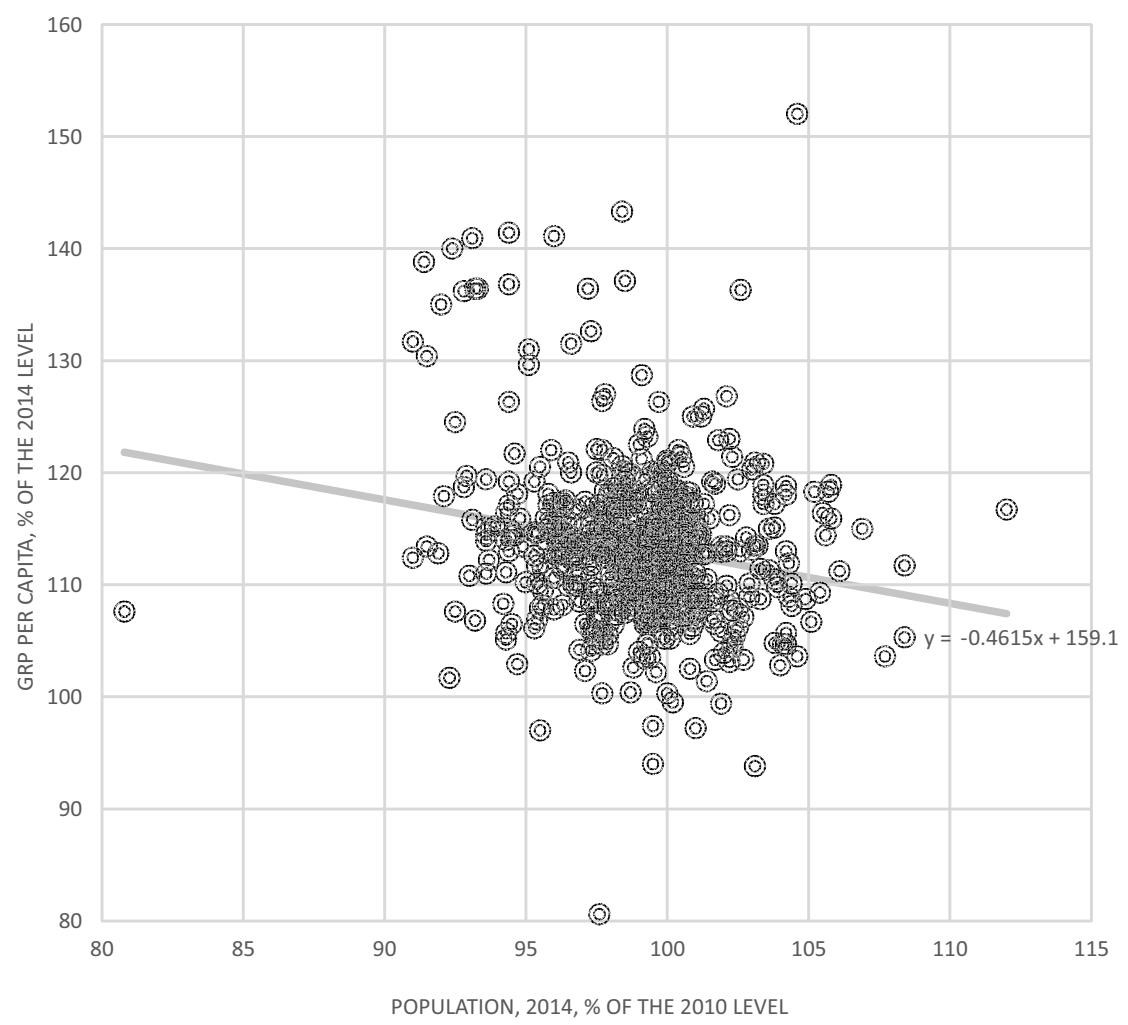

Figure 4. Distribution of Baltic region NUTS 3 territories by population and GRP per capita dynamics Source: based on on Eurostat and Rosstat statistical databases.

change and the rate of increase in GRP per capita. There is a trend towards people concentrating in densely populated areas, which is especially notable for the capital cities. However, the analysis do not support the thesis about the economic benefit of such concentration.

The interstate differences are rather significant. In Germany, the coefficient of linear correlation between the volume and dynamics of GRP per capita values is much lower than the macro-regional average. Probably, when equalization is attained, the generation of GRP per capita and the rate of regional development will not correlate. However, equalization is an outcome of many factors. We consider advanced countries showing the signs of a direct rather than an inverse correlation between the volume and change of GRP values - Denmark and Sweden have a very high positive correlation coefficient.

Our major conclusion is that the current level of development does not have a decisive effect on the future rates of national and regional economic growth. The emergence of new growth poles - which Paul Krugman considers as exceptions - necessitates a comprehensive analysis of internal and external impacts on economic development. Such an analysis is key to the integrated economic and geographical approach, which is rarely used in forecasting and strategic planning, particularly, in Russia.

As shown above, our analysis based on the Baltic region data does not confirm the economic benefits of the continuous growth of agglomerations and the concentration of people in the most densely populated are- 
as. Thus, the stimulation of large agglomerations seems to be a mistake from a general perspective and a potential environmental hazard. A more viable solution includes an evenly distributed settlement pattern and better transport accessibility.

Russia continues to devise the Strategy for Regional Socio-economic Development and to discuss which regions are to receive priority support - major agglomerations, which are believed to produce a more significant economic effect, or the periphery. However, neither national statistics nor the above analysis of the situation in the Baltic region proves the thesis about higher economic growth rates observed in more developed regions. We believe that additional support for industries and infrastructure should be provided to less developed regions. This will unlock regional potential, attract investment, and contribute to industrial specialisation.

Therefore, the key findings of the study is that data on GRP per capita, population density, and other indicators of spatial socio-economic development should not be absolutized in the strategic planning of regional development. There is a need for a comprehensive analysis and particularly for studying different factors affecting the current and prospective specialisation of each region (e.g. Chistobaev 2013; Gladkiy 2014; Baklanov 2016). Therefore, concentrating resources and efforts

\section{References}

AGH A. 2012. Global governance and integrative balancing: $E U$ efforts to respond to the global challenge. Journal of Global Policy, vol. 3, no. 2, pp. 145-153.

ANOKHIN A.A., FEDOROV G.M. 2017. The correlation of the processes of polarization and alignment of the level of social and economic development in the subjects of Russian Federation. Vestnik SPbGU. Nauki o Zemle, vol. 62, no 4. pp. 327-342. on supporting economic development in the most advanced regions or large agglomerations should not become a priority of the national regional policy.

We believe that, when devising national regional policies, it is important to shift emphasis from theoretical reflections on equalization and growth poles to specific regional conditions. It is also necessary to identify regional specialisation and its place in the territorial division of labour. There is a need to understand what areas require support in each region rather than to devise rules for identifying regions that qualify for support. The calculations taking into account all the internal and external factors of regional development will be more effective than theoretical structures.

$A$ reduction in the international and subregional economic differences in the Baltic region will contribute to the development of transnational and transboundary ties. Such ties are stronger between more developed countries. In their turn, stronger ties will increase the international competitiveness of all collaborating countries.

\section{Editors' note:}

Unless otherwise stated, the sources of tables and figures are the authors', on the basis of their own research.

Asheim B.T., Gertler M.S., 2009. The Geography of innovation: Regional innovation systems [in:] J. Fagerberg, D.D. Mowery (eds.), The Oxford handbook of innovation, Oxford: Oxford University Press.

BACKER H., 2011. Transboundary maritime spatial planning: A Baltic Sea perspective. Journal of Coastal Conservation, vol. 15, no. 2, pp. 279-289.

BAKLANOV P.YA., 2012. Notes on the article A.N. Pilyasova "New economic geography (neg) and its potential for studying the distribution of productive forces of Russia" Regionalnye issledovanija, vol. 2, no. 36, pp. 166-172. 
Baklanov P.YA., 2016. Geographical and geopolitical factors in regional development [in:] V.M., Kotlyakov, V.N. Streletskiy, O.B. Glezer, S.G. Safronov (eds.), Problems of regional development of Russia, Voprosy geografii, no. 141, Moscow: Kodeks Publishing house, pp. 166-175.

Berezhnoy V.I., Taran O.L., Berezhnaya O.V., ShURAKOVA M.M. 2017. Asimmetrija i prostranstvennaja poljarizacija razvitija regional'nyh social'no-èkonomičeskih sistem. Moscow: Rusajns.

BERGER-SCHMITT R., 2002. Social cohesion between the member states of the European Union: Past developments and prospects for an Enlarged Union. Sociologický časopis, vol. 38, no. 6, pp. 721-748.

BLoCKMANS W., 2006. Europe's history of integration and diversity. European Review, vol. 14, no. 2, pp. 241-256.

BoudeVILLE J., 1966. Problems of regional economic planning. Edinburgh: Edinburgh University Press.

BouRDIN S., 2013. A geographical approach to economic convergence. Exploring regional disparities in the European Union and their evoIution. L'Espace géographique (English Edition), vol. 42, no. 3, pp. 256-270

Camagni R., 2017. Territorial capital, competitiveness and regional development [in:] R. Huggins, P. Thompson (eds.), Handbook of regions and competitiveness: Contemporary theories and perspectives on economic development, Cheltenham: Edward Elgar Publishing.

CAPELlo R., 1999. Spatial transfers of knowledge in high technology milieux: Learning versus collective learning processes. Regional Studies, vol. 33, no. 4, pp. 353-366.

Capello R., Caragliu A., Nijkamp P., 2011. Territorial capital and regional growth: Increasing returns in knowledge use. Tijdschrift voor economische en sociale geografie, vol. 102, no. 4, pp. 385-405.

Capello R., Faggian A., 2005. Collective learning and relational capital in local innovation processes. Regional Studies, vol. 39, no. 1, pp. 75-87.

Caragliu A., Nijkamp P., 2016. Space and knowledge spillovers in European regions: The impact of different forms of proximity on spatial knowledge diffusion. Journal of Economic Geography, vol. 16, no. 3, pp. 749-774.
Chistobaev A.I., 2013. Prostranstvennoe planirovanie $v$ Rossii: Sostojanie, problemy, zadači geografov. Social'no-èkonomičeskaja geografija. Vestnik Associacii rossijskih geografov-obsestvovedov, vol. 1, no. 2, pp. 15-24.

De Dominicis L., 2014. Inequality and growth in European Regions: Towards a place-based approach. Spatial Economic Analysis, vol. 9, no. 2, pp. 120-141.

Delhey J., Kohler U., 2006. From nationally bounded to pan-European inequalities? On the importance of foreign countries as reference groups. European Sociological Review, vol. 22, no. 2, pp. 125-140.

DruZHinIN P.V., Prokopyev E.A., 2018. An assessment of the economic performance of the $E U$ Baltic Region States. Baltic Region, vol. 10, no. 1, pp. 4-18.

Dyba W., Loewen B., LoOga J., Zdražll P., 2018. Regional development in Central-Eastern European countries at the beginning of the 21st Century: Path dependence and effects of EU cohesion policy. Quaestiones Geographicae, vol. 37, no. 2, pp. 77-92.

EpsteIn R.A., 2014. Overcoming 'economic backwardness' in the European Union. Journal of Common Market Studies, vol. 52, no. 1, pp. 17-34.

FrIEDMANN J., 1967. A general theory of polarized development. Ford Foundation, Urban and Regional Development Advisory Program in Chile, Santiago.

Garretsen H., Martin R., 2010. Rethinking (new) economic geography models: Taking geography and history more seriously. Spatial Economic Analysis, vol. 5, no. 2, pp. 127-160.

GASPAR J., 2018. A prospective review on New Economic Geography. Annals of Regional Science, vol. 61, no. 2, pp. 237-272.

GLADKIY Yu. 2014. The questions of optimization of inter-regional proportions in Russia: the dangerous range of opinion. Vestnik ARGO, no. 3, pp. 41-50.

GyURIS F., 2013. The political discourse of spatial disparities: Geographical inequalities between science and propaganda. Berlin: Springer.

Hassink R., Gong H. (eds.), 2016. New economic geography [in:] A.M. Orum, M. Garcia, D. Judd, B. Roberts, P.C. Piew (eds.), Wiley-Blackwell Encyclopedia of Urban and Regional Studies. London: Wiley-Blackwell. 
KeRN K., LÖFFELSEND T., 2004. Sustainable development in the Baltic Sea Region. Governance beyond the nation state. Local Environment, vol. 9, no. 5, pp. 451-467.

KINOSSIAN N., 2013. Stuck in transition: Russian regional planning policy between spatial polarization and equalization. Eurasian Geography and Economics, vol. 54, no. 5-6, pp. 611-629.

KirYushin P., Mulloth B., Iakovleva T., 2013. Developing cross-border regional innovation systems with clean technology entrepreneurship: The case of Øresund. International Journal of Innovation and Regional Development, vol. 5, no. 2, pp.179-195.

Klemeshev A.P., Korneevets V.S., Palmowski T., StudZIenieCKI T., Fedorov G.M., 2017. Approaches to the definition of the Baltic Region. Baltic Region, vol. 9, no. 4, pp. 4-20.

KocH K., 2015. Region-building and security: The multiple borders of the Baltic Sea region after EU enlargement. Geopolitics, vol. 20, no. 3, pp. 535-558.

Koliousis I.G., Papadimitriou S., Riza E., StavrouLAKIS P.J., TsIOUmas V., 2018. Scarcity theory and maritime clusters: From paradox to modelling. Marine Policy, vol. 93, pp. 40-46.

Kretinin G.V., Katrovskiy A.P., Pototskaya T.l., Fedorov G.M., 2016. Geopolitical and geo-economic changes in the Baltic Sea Region at the turn off the $X X-X X I$ centuries. Baltic Region, no. 4, pp. 13-25.

Krugman P., 1991. Geography and trade. Cambridge, MA: MIT Press.

LASUEN J.R., 1969. On growth poles. Urban Studies, vol. 6, no. 2, pp. 137-161.

LEPIK K.-L., 2009. Euroregions as mechanisms for strengthening cross-border cooperation in the Baltic sea region. Trames, vol. 13, no. 3, pp. 265-282.

Makhrova A.G., Nefedova T.G., Treyvish A.I., 2016. The central Russian megalopolis: polarization of space and population mobility. Moscow University Bulletin, series 5, Geography, pp. 77-85 [in Russian].

MeLNIKAS B., 2008a. Integral spaces in the European Union: Possible trends of the social, economic and technological integration in the Baltic region. Journal of Business Economics and Management, vol. 9, no. 1, pp. 65-77.
MeLNIKAS B., 2008b. Integration processes in the Baltic region: The new form of regional transformations in the European Union. Engineering Economics, vol. 5, no. 60, pp. 54-64.

Melnikova L.V., 2014. Regional economics seeking consensus, regional policy looking for targets. ECO, vol. 44, no. 4, pp. 28-51.

MezheVich N.M., Kretinin G.V., Fedorov G.M., 2016. Economic and geographical structure of the Baltic Sea Region. Baltic Region, vol. 8, no. 3, pp. 11-21.

MikHailova A.A., 2013. Innovation capacity of Russia and the Baltics: A comparative approach. Baltic Region, no. 1 (15), pp. 91-100.

Mikhaylov A.S., Mikhaylova A.A., 2014. Spatial and sectoral distribution of international clusters in the Baltic region. European Journal of Scientific Research, vol. 121, no. 2, pp. 122-137.

MoRgan K., 2007. The learning region: Institutions, innovation and regional renewal. Regional Studies, no. 41:S1, pp. 147-159.

NizHEgorodtseV R.M., 2008. Poljarizacija èkonomičeskogo prostranstva Rossii i zadači èkonomičeskoj nauki. Vestnik ekonomicheskoy integratsii, no. 3, Moskva: Izdatel'stvo: Integracija, pp. 5-10

PAAS T., 2003. Regional integration and international trade in the context of EU eastward enlargement. HWWA Discussion Paper, no. 218, Hamburg: Institute of International Economics.

Pacuk M., Palmowski T., Tarkowski M., 2018. The emergence of Baltic Europe: An overview of Polish research on regional integration. Quaestiones Geographicae, vol. 37, no. 2, pp. 47-60.

PARK S.-C., 2014. Innovation policy and strategic value for building a cross-border cluster in Denmark and Sweden. Al \& Society, vol. 29, no. 3, pp. 363-375.

Perroux F. 1955. Note sur la notion de 'pôle de croissance. Économique Appliquée, no.7, pp. 307-320.

Perucca G., 2014. The role of territorial capital in local economic growth: Evidence from Italy. European Planning Studies, vol. 22, no. 3, pp. 537-562.

Petruzzelli A.M., Albino V., Carbonara N., 2009. External knowledge sources and proximity. Journal of Knowledge Management, vol. 13, no. 5 , pp. 301-318. 
Pettersson T., 2002. Social capital and traditional-conservative values in the Baltic region [in:] W. Maciejewski (ed.), The Baltic Sea Region Cultures, Politics, Societies, pp. 165-225.

PILYASOV A.N., 2011. New economic geography and its contribution to the studies of placement of productive forces in Russia. Regionalnye issledovaniya, vol. 1, no. 13, pp. 3-31.

ROHDE S., 2016. Industry clusters across national borders: Lliterature review and research deficits. International Journal of Entrepreneurship and Small Business, vol. 29, no. 2, pp. 338-358.

ScotT J.W., 2002. Cross-border governance in the Baltic Sea region. Regional \& Federal Studies, vol. 12, no. 4, pp. 135-153.

ScotT J.W., 2002. Baltic Sea regionalism, EU geopolitics and symbolic geographies of co-operation. Journal of Baltic Studies, vol. 33, no. 2, pp. 137-155.
Seliverstov V.E., 2008. Dve modeli regionalnoj politiki. ECO, no. 4, pp. 88-92.

StEAD D., 2013. Convergence, divergence, or constancy of spatial planning? Connecting theoretical concepts with empirical evidence from Europe. Journal of Planning Literature, vol. 28, no. 1, pp. 19-31.

Тотн B.I., 2014. Territorial capital: Theory, empirics and critical remarks. European Planning Studies, vol. 23, no. 7, pp. 1327-1344.

Williamson J.G., 1965. Regional inequality and the process of national development: A description of patterns. Economic Development and Cultural Change, vol. 13, no. 4, part 2, pp. 1-84.

ZUBAREVICH N., 2015. The relations between the center and the regions [in:] M. Lipman, N. Petrov (eds.), The state of Russia: What comes next?, Houndmills: Palgrave Macmillan, pp. 50-68. 
